\title{
Sheltered adolescents' background of exposure to violence and distressful experiences
}

\author{
Exposição à violência e experiências difíceis vividas por adolescentes em situação de acolhimento institucional
}

Exposición a la violencia y experiencias difíciles vividas por adolescentes en situación de acogida institucional

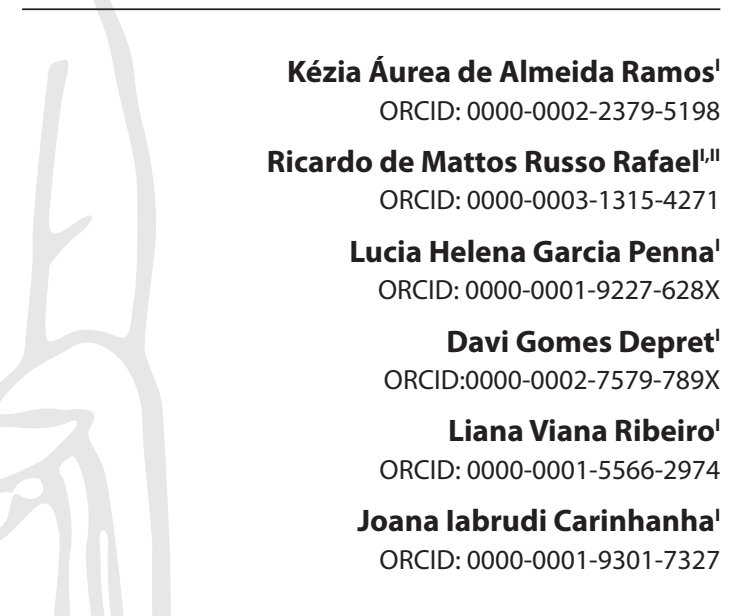

'Universidade do Estado do Rio de Janeiro. Rio de Janeiro, Rio de Janeiro, Brazil. "Universidade Estácio de Sá. Rio de Janeiro, Rio de Janeiro, Brazil.

How to cite this article: Ramos KAA, Rafael RMR, Penna LHG, Depret DG, Ribeiro LV, Carinhanha JI. Sheltered adolescents' background of exposure to violence and distressful experiences. Rev Bras Enferm. 2020;73(4):e20180714. doi: http://dx.doi.org/10.1590/0034-7167-2018-0714

Corresponding author:

Ricardo de Mattos Russo Rafael

E-mail: prof.ricardomattos@gmail.com

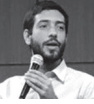

EDITOR IN CHIEF: Dulce Aparecida Barbosa ASSOCIATE EDITOR: Priscilla Valladares Broca

Submission: 09-04-2018

Approval: 05-29-2019

\begin{abstract}
Objectives: to analyze the exposure to violence and distressful experiences lived by adolescents in institutional shelters in the city of Rio de Janeiro (previous to their admittance). Methods: a crosssectional study carried out in public institutional shelter units, with a sample of 72 adolescents aged between 12 and 18 years. Data on sociodemographic aspects, family relationships and distressful experiences were obtained by means of the Parcours Amoureux des Jeunes instrument, validated for use in Brazil. Statistical analysis included estimates of prevalence and $95 \%$ confidence intervals. Results: high magnitudes of distressful experiences and overlapping abuses lived by adolescents were observed, especially violent events (72.2\%), social exclusion (59.1\%), and sexual harassment (48.6\%). Conclusions: the study shows that adolescents under institutional sheltering come from a background of severe and frequent distressful experiences. These took place in multiple environments: family (prior to their institutional reception), community, and group.

Descriptors: Adolescent; Institutionalized Adolescent; Violence; Exposure to Violence; Street Drugs.
\end{abstract}

\section{RESUMO}

Objetivos: analisar a exposição à violência e experiências difíceis vivenciadas por adolescentes em situação de acolhimento institucional no município do Rio de Janeiro. Métodos: estudo transversal realizado nas unidades públicas de acolhimento institucional, com amostra de 72 adolescentes entre 12 e 18 anos. A aferição dos aspectos sociodemográficos, das relações familiares e das difíceis experiências foi realizada por meio do instrumento Parcours Amoureux des Jeunes, validado para uso no Brasil. A análise estatística contou com estimações de prevalências e intervalos de confiança a 95\%. Resultados: foram observadas elevadas magnitudes de experiências difíceis e com sobreposição de abusos vividos pelos adolescentes, com destaque para os eventos violentos $(72,2 \%)$, a exclusão social $(59,1 \%)$ e o assédio sexual $(48,6 \%)$. Conclusões: o estudo revelou elevadas e múltiplas magnitudes de experiências difíceis experenciadas pelos adolescentes em acolhimento institucional, tanto no âmbito familiar, em momentos prévios ao acolhimento, como em âmbito comunitário e grupal.

Descritores: Adolescente; Adolescente Institucionalizado; Violência; Exposição à Violência; Drogas llícitas.

\section{RESUMEN}

Objetivos: analizar la exposición a la violencia y las experiencias difíciles vividas por adolescentes en situación de acogida institucional en la ciudad de Río de Janeiro. Métodos: estudio transversal realizado en unidades públicas de acogida institucional, con una muestra de 72 adolescentes entre 12 y 18 años de edad. La medición de los aspectos sociodemográficos, de las relaciones familiares y de las experiencias difíciles se realizó mediante el instrumento Parcours Amoureux des Jeunes, validado suuso en Brasil. El análisis estadístico contó con estimaciones de prevalencias e intervalos de confianza al $95 \%$. Resultados: se observaron altas magnitudes de experiencias difíciles, con superposición de abusos vividos por los adolescentes, en particular los eventos violentos $(72,2 \%)$, la exclusión social $(59,1 \%)$ y el acoso sexual $(48,6 \%)$. Conclusiones: el estudio reveló altas y múltiples magnitudes de experiencias difíciles experimentadas por los adolescentes en acogida institucional tanto en el ámbito familiar, en momentos anteriores a la acogida, como en el ámbito comunitario y grupal.

Descriptores: Adolescente; Adolescente Institucionalizado; Violencia; Exposición a la Violencia; Drogas Ilícitas. 


\section{INTRODUCTION}

Conceived of in uncertain terms, hardly based on a theoretical consensus, the multifarious period known as adolescence has been gaining space in public health research agendas worldwide and in Brazil. This phenomenon is partly related to obstacles standing in the way of this population's recruitment and adherence to health promotion and health care programs. Generally speaking, these programs have failed to adapt to the adolescent public's plurality of needs and demands, being carried out in a normative and imposing way, in order to establish so-called healthy habits. Another reason for this lies in how challenging it is to reduce this group's complex experiences into a unified concept of adolescence ${ }^{(1)}$.

While attempting to avoid the dangers of such a reduction, this study focuses precisely on adolescent experiences, considering its multiple meanings as a background for the debate on adolescence. Thus, adolescence is understood here as a period of human development defined by the construction of identities, the search for autonomy in relation to family and society, and the (re)discovery of affective relationships, whether permeated by family, sex, love or group. The reason for this theoretical option is based on the understanding that this period is not strictly related to one's age or to the physiological development stage of one's sexual and reproductive functions ${ }^{(2)}$.

During adolescence, the family ceases to be the only important agent of socialization, giving way to relationships with one's peers. This kind of socialization and interaction among friends usually takes place over a prolonged period of time. Furthermore, these relationships become more stable as adolescents externalize intimate issues, such as feelings and secrets that they are not always allowed to share with their parents. Thus, relationships with peers become increasingly important, insofar as they mediate the construction of identity and social roles. Adolescents thus become simultaneously singular and social subjects, helping build the norms they intend to follow while acting as references for their respective groups of peers. The acceptance of oneself and the other begins to permeate this new network of relationships, which is in a state of constant construction ${ }^{(3-5)}$.

The literature points out that family, group and other contextual experiences arising from social relations are either protective or risk factors in respect to each individual's human development path. That is, the experiences lived during this stage seem to bear heavily on adulthood's behaviors, practices, and attitudes. Examples of predictive factors based on adolescent experiences are the use of tobacco, alcohol and other drugs, as well as the recourse to violence to resolve conflicts during intimate relationships $^{(6-8)}$. In addition, numerous negative outcomes have been linked to distressful experiences during this phase. Examples are the association between violence suffered in adolescence and lower economic and educational development in adults, as well as increased risk of suicide, mental disorders, and other outcomes that entail negative consequences and psychic suffering ${ }^{(9-11)}$.

Thus, the different ways adolescence is experienced - by adolescents themselves or their families - has implications on other phases of the life cycle. In an attempt to establish a protective network for children, adolescents and young people whose social and family relationships present socio-affective ruptures jeopardizing human development, the institutional shelter strategy was proposed by the Child and Adolescent Statute. Alongside a series of other devices, shelters constitute a support and protection network for children and adolescents who live (or have lived) in situations that are threatening to life and full human development ${ }^{(12)}$.

On the other hand, there is still a lack of scientific production on the experiences taking place within this group's family and contextual sphere. This is partly due to the social and academic invisibility to which adolescents are subjected, and partly due to the difficulty of recruiting adolescents and young people who have gone through violent experiences - which complicates the operationalization of studies in the area. Thus, this study is based on the premise that the construction of social and affective bonds between should not be viewed and analyzed in a linear and standardized way, as this could lead to an hermetic representation of the contexts in which adolescents are inserted.

\section{OBJECTIVES}

To analyze the exposure to violence and distressful experiences of adolescents living in institutional shelters in the city of Rio de Janeiro.

\section{METHODS}

\section{Ethical aspects}

The research protocol respected the ethical precepts determined by Resolution 466/2012 of the National Health Council. It was appreciated and approved by the Research Ethics Committee of the State University of Rio de Janeiro. Since this was a study involving adolescents in an institutional sheltering situation, in compliance with the legal system and other technical devices of the children and adolescent protection network, those responsible for each shelter unit signed an Informed Consent term. After the objectives and protocols of the study were presented to the participating adolescents, and prior to the start of the interviews, they signed an Informed Agreement term. In addition, the premises of anonymity, privacy during data collection, and possibility of withdrawal of the authorization at any time were fully respected, following the recommendations on research involving people in situations of violence $^{(13)}$. Moreover, all interviews were conducted by women.

\section{Design, local and period of study}

This was an observational cross-sectional study anchored in the project entitled "Violence in the intimate affective relationships of adolescents in an institutional sheltering setting in the city of Rio de Janeiro: the gender perspective and its interfaces with Health and Nursing" (Violência nas relações afetivas íntimas de adolescentes em situação de acolhimento institucional no município do Rio de Janeiro: perspectiva de gênero e suas interfaces com a Saúde e a Enfermagem).

The study was developed in the city of Rio de Janeiro, located in the state's metropolitan region. The municipality has one of the biggest economies in the country, besides being an important social and cultural center. With a population of 15,989,929 inhabitants, it 
also has a high number of young people living in socially vulnerable and peripheral areas. Given the complexity of the municipal territory, the institutional shelter network for children and adolescents accounts for $30 \%(n=53)$ of the state's public and private facilities network ${ }^{(14)}$. The municipality's sheltering network for adolescents is comprised of 11 private institutions and seven public ones.

The study scenario included all public units, with the exception of Casas Vivas - which exclusively shelters adolescents dealing with abusive consumption of alcohol and other drugs, as this could bias the study that originated this manuscript. Admittance and Screening centers were also excluded, due to their high turnover of young people.

\section{Study population and selection criteria}

Using a non-probabilistic, convenience sampling technique, the study's population was comprised of the total number of adolescents between 12 and 18 years old who were in an institutional sheltering situation during the study period. This amounted to 91 subjects. Given the main study's object, adolescents who had experienced at least one affective-intimate relationship (dating or 'hooking up' with someone) in the last 12 months prior to the collection ( $n=90$ ) were included; excluded were those who were not found in the shelter after three unsuccessful recruitment attempts (at distinct times and days of the week), as well as those who declined to participate in the study $(n=18 ; P=20.0 \%)$. Thus, the final sample consisted of 72 participants.

\section{Study protocol}

The collection procedures were previously standardized by the study's coordinators, in order to ensure the reproducibility of the data and the observance of the principles that ensure the validity of epidemiological studies. To this end, the six interviewers received training on the topics being researched, as well as on procedures of collection and conduct in adverse cases. After authorization by the Training Center of the Municipal Department of Social Assistance of the city of Rio de Janeiro, the interviewers' initial approaches in the sheltering units had the goal of getting to know the study's participants, as well as establishing mutual recognition. Meetings with theunits' adolescents and workers were carried out to plan the interviews, and select private places where they could be carried out.

Data collection took place via face-to-face interviews, using a structured and multidimensional script. The first dimension of the instrument was comprised of Parcours Amoureux des Jeunes (PAJ) scales, transculturally adapted and validated for use in Brazil ${ }^{(15)}$. The instrument, originally conceived by the Research Group on Violence and Health (Evissa) at the University of Quebec in Montreal, is composed of seven sections, regarding general and sociodemographic information, affective relationships, distressful experiences, sexual behaviors, family, behaviors and life habits, and feelings and emotions.

The second and third dimensions were built from the Alcohol Smoking and Substance Involvement Screening Test (Assist 2.0) and the Conflict in Adolescent Dating Relationships Inventory (Cadri), both also validated for Brazilian use ${ }^{(16-19)}$. Considering this study's objectives, we hereby present in the analysis of three PAJ scales: general information, affective relationships, and distressful experiences.

\section{Analysis of results and statistics}

A database was built using Epilnfo 3.5.1 software, with double typing of $20 \%$ of the collected data. Statistical preparation, processing and descriptive analysis of prevalence as well as $95 \%$ confidence intervals were performed using Stata SE 13.0 software.

\section{RESULTS}

The sample's demographic characterization shows that participants' ages ranged from 12 to 18 years, with a concentration between 12 and 15 years $(n=42 ; 58.3 \%)$. Most of the interviewed adolescents ( $n=46 ; 63.9 \%)$ were males, blacks $(n=63 ; P=87.3 \%)$ and only had elementary schooling $(n=59 ; P=81.9 \%)$. It should be noted that a significant number of participants had not lived long enough with parents or guardians so as to be able to answer all questions, and this led to a series of blank responses. The number of adolescents who provided blank answers varied from 4 to 27 , depending on the question.

Table 1 presents sets of family experiences these adolescents had to endure before being granted institutional sheltering. The ingestion of alcoholic beverages by parents or guardians was the most common experience in regards to licit drugs, followed by tobacco consumption (especially by the paternal figure). As for experiences with illict drugs, males had 2.3 times more chance of being the culprit. According to the data, $37.1 \%$ of the adolescents reported having witnessed the consumption of this kind of drug by their parents. Also noteworthy is that $33.3 \%$ and $25.8 \%$ of adolescents reported having witnessed paternal and maternal figures respectively attacking and being attacked by other relatives. In respect to intimate partner violence, we highlight the frequent physical abuse (pulling, pushing, slapping, etc.) and grave physical abuse (threatening with knife or weapon, punching or kicking, etc.) perpetrated by paternal and maternal figures.

Table 2 describes the set of distressful experiences lived by the group of adolescents studied. It is noteworthy that more than half of the interviewed participants reported having witnessed some form of violence against another person, having experienced death or serious illness of a relative, having been excluded from their social milieu, and/or having suffered bullying at school. The lower prevalence notwithstanding, it is important to highlight the significant occurrences of sexual harassment, sexual assault (involving penetration), and physical violence experienced by the group of interviewees.

Table 3 shows experiences witnessed within the friendship sphere (i.e., experienced by friends of each member of the group), as presented by the interviewed adolescents. On the one hand, it is important to point out that, with the exception of the consumption of alcoholic beverages, cigarettes and marijuana, all the reported informational categories had a lower than $50 \%$ prevalence when referring to 'most' or 'all' of the interviewees' friends. On the other hand, the prevalence across all positive answers ('one,"some,"most' and 'all') surpassed $50 \%$ in 7 of the 12 situations. In addition, $23.6 \%$ of the sample had no knowledge of sexual violence situations among friends. 
Table 1 - Experiences of drug use and aggression reportedly experienced by adolescents before being granted institutional sheltering, as perpetrated by their parents or guardians, Rio de Janeiro, Rio de Janeiro, Brazil, 2017

\begin{tabular}{|c|c|c|}
\hline Variables & $\mathbf{N}$ & n (\%; $95 \% \mathrm{Cl})$ \\
\hline \multicolumn{3}{|l|}{ Witnessed the father figure: } \\
\hline Smoking cigarettes & 60 & $31(51.7 ; 38.8 / 64.3)$ \\
\hline Drinking alcohol & 63 & $48(76.2 ; 63.8 / 85.3)$ \\
\hline Using other drugs & 62 & $23(37.1 ; 25.8 / 50.0)$ \\
\hline Assaulting other family members & 63 & $21(33.3 ; 22.6 / 46.1)$ \\
\hline Being assaulted by other family members & 62 & $12(19.3 ; 11.1 / 31.4)$ \\
\hline \multicolumn{3}{|l|}{ Assaulting the mother/maternal figure } \\
\hline Insulting, cursing, screaming & 61 & $35(57.4 ; 44.4 / 69.4)$ \\
\hline Threatening to drop, destroy an object belonging to another & 59 & $22(37.3 ; 25.7 / 50.6)$ \\
\hline Pulling, pushing, slapping, twisting someone's arm, throwing an object capable of injuring at someone & 59 & $25(42.4 ; 30.2 / 55.6)$ \\
\hline Threatening with knife or weapon, punch or kick, brutally push against the wall & 59 & $17(28.8 ; 18.4 / 42.0)$ \\
\hline \multicolumn{3}{|l|}{ Witnessed the maternal figure: } \\
\hline Smoking cigarettes & 67 & $30(44.8 ; 53.9 / 76.6)$ \\
\hline Drinking alcohol & 45 & $30(66.2 ; 53.9 / 76.6)$ \\
\hline Using other drugs & 68 & $11(16.2 ; 9.0 / 27.2)$ \\
\hline Assaulting other family members & 68 & $18(26.5 ; 17.1 / 38.5)$ \\
\hline Being assaulted by other family members & 66 & $17(25.8 ; 16.4 / 37.9)$ \\
\hline \multicolumn{3}{|l|}{ Assaulting the father or father figure } \\
\hline Insulting, cursing, screaming & 62 & $36(58.1 ; 45.2 / 70)$ \\
\hline Threatening to drop, destroy an object belonging to another & 61 & $26(42.6 ; 30.6 / 55.6)$ \\
\hline Pulling, pushing, slapping, twisting someone's arm, throwing an object capable of injuring at someone & 61 & $21(34.4 ; 23.4 / 47.5)$ \\
\hline Threatening with knife or weapon, punch or kick, brutally push against the wall & 61 & $18(29.5 ; 19.2 / 42.4)$ \\
\hline
\end{tabular}

Table 2 - Distressful experiences lived by adolescents in institutional shelters, Rio de Janeiro, Rio de Janeiro, Brazil, 2017

\begin{tabular}{llc}
\hline Variables & N & n (\%; IC 95\%) \\
\hline Witnessed violence against someone & 72 & $52(72.2 ; 60.5 / 81.5)$ \\
Was excluded from social milieu & 71 & $42(59.1 ; 47.1 / 70.1)$ \\
Suffered bullying in social media & 71 & $28(39.4 ; 28.5 / 51.4)$ \\
Suffered bullying at school & 72 & $38(52.8 ; 41.0 / 64.2)$ \\
Was physically assaulted by a relative & 72 & $18(25.0 ; 16.1 / 36.5)$ \\
Was subjected to sexual harassment & 72 & $35(48.6 ; 37.0 / 60.2)$ \\
Was subjected to sexual assault & 65 & $20(30.8 ; 20.5 / 43.2)$ \\
\hline
\end{tabular}

\section{DISCUSSION}

The analysis made it possible to recognize the distressful experiences lived by a group of adolescents in institutional sheltering, in an attempt to map their exposure to violence, providing subsidies for the debate on public health care policies targeting this group. Even with the difficulties involved in the recruitment of these adolescents - who often develop defense and protection mechanisms, becoming more reserved — the use of certain strategies made it possible to maintain acceptable levels (20\%) of sample loss and interview refusals. Among these strategies,

Table 3- Experiences witnessed in the friendship sphere by adolescents in institutional shelters, Rio de Janeiro, Rio de Janeiro, Brazil, 2017 ( $\mathrm{n}=72$ )

\begin{tabular}{|c|c|c|c|c|c|c|}
\hline \multirow{2}{*}{ Variables } & \multicolumn{6}{|c|}{$\%(95 \% \mathrm{Cl})$ Friends } \\
\hline & None & One & Some & Most & All & Does not know \\
\hline Dropping out of school & $29.2(19.6 / 40.9)$ & $2.8(0.6 / 10.7)$ & $30.6(20.8 / 42.3)$ & $25.0(16.1 / 36.5)$ & $9.7(4.6 / 19.3)$ & $2.8(0.6 / 10.7)$ \\
\hline \multicolumn{7}{|l|}{ Drug consumption } \\
\hline Cigarettes & $12.5(6.5 / 22.6)$ & $4.2(1.3 / 12.4)$ & $23.6(15.0 / 35.0)$ & $23.6(15.0 / 35.0)$ & $34.7(24.4 / 46.6)$ & $1.4(0.1 / 9.6)$ \\
\hline Alcoholic beverages & $8.3(3.7 / 17.6)$ & $4.2(1.3 / 12.4)$ & $13.9(7.5 / 24.2)$ & $25.0(16.1 / 36.5)$ & $45.8(34.4 / 57.6)$ & $2.8(0.6 / 10.7)$ \\
\hline Marijuana & $19.4(11.7 / 30.5)$ & $4.2(1.3 / 12.4)$ & $18.1(10.6 / 28.9)$ & $26.4(17.3 / 38.0)$ & $29.2(19.6 / 40.9)$ & $2.8(0.6 / 10.7)$ \\
\hline Crack & $80.6(69.4 / 88.2)$ & $1.4(0.1 / 9.6)$ & $4.2(1.3 / 12.4)$ & $1.4(0.1 / 9.6)$ & $4.2(1.3 / 12.4)$ & $8.3(3.7 / 17.6)$ \\
\hline Cocaine & $75.0(63.4 / 83.8)$ & $4.2(1.3 / 12.4)$ & $5.6(2.0 / 14.1)$ & $2.8(0.6 / 10.7)$ & $4.2(1.3 / 12.4)$ & $8.3(3.7 / 17.6)$ \\
\hline Others & $31.9(22.0 / 43.8)$ & $6.9(2.8 / 15.9)$ & $25.0(16.1 / 36.5)$ & $13.9(7.5 / 24.2)$ & $11.1(5.5 / 20.9)$ & $11.1(5.5 / 20.9)$ \\
\hline \multicolumn{7}{|l|}{ Juvenile offenses } \\
\hline Disrespect for traffic laws & $47.2(35.7 / 58.9)$ & $4.2(1.3 / 12.4)$ & $13.9(7.5 / 24.2)$ & $12.5(6.5 / 22.6)$ & $13.9(7.5 / 24.2)$ & $8.3(3.7 / 17.6)$ \\
\hline Provoking accidents & $58.3(46.4 / 69.3)$ & $8.3(3.7 / 17.6)$ & $18.1(10.6 / 28.9)$ & $2.8(0.6 / 10.7)$ & $1.4(0.1 / 9.6)$ & $11.1(5.5 / 20.9)$ \\
\hline Vandalism & $40.3(29.3 / 52.2)$ & $5.6(0.2 / 14.1)$ & $13.9(7.5 / 24.2)$ & $11.1(5.5 / 20.9)$ & $20.8(12.8 / 32.0)$ & $8.3(3.7 / 17.6)$ \\
\hline \multicolumn{7}{|l|}{ Victim of IPV*: } \\
\hline Physical & $40.3(29.3 / 52.2)$ & $13.9(7.5 / 24.2)$ & $18.1(10.6 / 28.9)$ & $15.3(8.5 / 25.8)$ & $2.3(0.6 / 10.7)$ & $9.7(4.6 / 19.3)$ \\
\hline Sexual & $48.6(37.0 / 60.2)$ & $8.3(3.7 / 17.6)$ & $12.5(6.5 / 22.6)$ & $1.4(0.1 / 9.6)$ & $5.6(0.2 / 14.1)$ & $23.6(15.0 / 35.0)$ \\
\hline
\end{tabular}


the following stand out: the use of female interviewers with previous experience working with adolescents; the practice of making preliminary visits with the main goal of creating mutual awareness and recognition; the study's design, which considered all eligible institutional shelter units.

The multifarious phenomenon of violence has been the subject of several investigations and theoretical-practical debates attempting to mitigate its consequences over people's lives. The adoption of an operational notion, as proposed in the World Health Organization's "World report on violence and health," appears to be a promising solution to the conceptual imbroglio imposed by violence's mutability and cultural flexibility ${ }^{(20-21)}$. According to this notion, the concept of violence is understood as the "intentional use of physical force or power, threatened or actual, against oneself, another person, or against a group or community, that either results in or has a high likelihood of resulting in injury, death, psychological harm, maldevelopment or deprivation"(21).

The multiple distressful experiences and abuses lived by young people in affective-familial relationships and in group relations certainly stand out among the results of this study. It is important to consider that, although high, the prevalence of intimate psychological abuse among adolescents' paternal and maternal figures is lower than observed in the general population ${ }^{(22-23)}$. However, it is equally important to note that prevalences of physical and grave physical abuse were high. Research conducted in Rio de Janeiro indicated that the prevalence of physical violence among couples is estimated to range between $20 \%$ and $30 \%$, while the prevalence of grave physical violence is between $6 \%$ and $14 \%^{(23-24)}$. In addition, the probable family breakdown preceding adolescents' admittance may have been responsible for the significant rate of blank responses - ranging from $5 \%$ to $33 \%$ in items aimed at mapping social relationships established prior to shelter.

More than $70 \%$ of adolescents interviewed witnessed some type of violence, whether in the community, family, or groups of friends. The international literature shows that, although this phenomenon is present in different contexts and age groups, some populations are more exposed to it, especially when considering age, gender, schooling, ethnicity, and income characteristics. Unsurprisingly, adolescence has been regarded as the period of life most vulnerable to being exposed to violence ${ }^{(25)}$. Although important for the construction of identities, the search for autonomy, which occurs when a person experiences new environments and social groups, also leads to an increased risk of behaviors that could be controlled in other social environments such as the family (as long as it is minimally structured) (26).

A study conducted in a reference hospital in Belo Horizonte identified that $64.7 \%$ of the emergency services provided to adolescent victims of violence were due to physical attacks ${ }^{(27)}$. In a study conducted with schoolchildren from Brasília, which aimed to assess the prevalence of violence suffered by adolescents, prevalences of $85.4 \%$ and $34.7 \%$ were found for physical and sexual abuse, respectively ${ }^{(28)}$. Studies on violence during dating found magnitudes of violent events similar to those seen in the groups of adolescents investigated here ${ }^{(19)}$.

The multiplicity of abusive experiences reported by these young people, including social segregation and cyber-violence, seem to be in line with experiences lived by their peers. This is made clear by the range of distressful experiences reported in the categories "most [friends]" and "all [friends]" — these included the use of alcohol, tobacco and other drugs, as well as violent behavior. It is worth pointing out that group involvement has been characterized as either a risk or protective factor during adolescence, since it can potentiate beneficial or maleficial patterns of behavior that are being established during this phase $\mathrm{e}^{(3-5)}$.

Relationships of adolescents in institutional shelters are indeed marked by common situations of antisocial behavior and consumption of alcohol, tobacco and, to a lesser extent, marijuana. School evasion is also associated with this context. The sheltered adolescent is vulnerable to the development of deviant behaviors, as verified in the stage-based Social Interactional Model(29). This model maintains that the association with deviant peers is strongly related to the use of alcohol and other drugs, antisocial behaviors, and, often, dropping out of school.

The recent release of updated data on violence in Brazil has taken place in a context marked by the reproduction of poverty and social inequalities. With a chapter entitled "Juventude perdida" (Lost youth), the results of a study conducted by the Institute for Applied Economic Research and by the Fórum Brasileiro de Segurança Pública (Brazilian Forum on Public Safety) show the worsening of homicide among adolescents and young people, generally men, blacks and dwellers of peripheral areas ${ }^{(30)}$. In this context, Rio de Janeiro is among the 10 states with the highest rates of youth homicide. Thus, analyzing these data in the light of risks and vulnerabilities seems urgent. The magnitude of the problem faced by these adolescents and their social groups needs to be made public, since only a situation recognized as problematic can be effectively deconstructed ${ }^{(31)}$.

A study carried out in the same scenario as this research has already indicated that adolescents themselves already recognize abuse - and, by theoretical approximation, distressful experiences - as problematic. That is, this group tends to understand that the use of violence as a tactic of conflict resolution and as a form of expression - such as vandalism - is unjustifiable and unacceptable. However, the same study argues that this elaboration seems to be punctual and idealized, hardly indicating that these practices will actually be avoided ${ }^{(32)}$. Another classic research, dating from the 1960s and conducted in the field of social psychology, states that the way people behave in the face of concrete situations bears little relation to their philosophical and moral idealizations ${ }^{(33)}$.

These habits and experiences may not only lead this group to negative physical and psychosocial consequences, but also offer a window of opportunity for their continued reiteration ${ }^{(9-11)}$. Breaking with the naturalization of violent phenomena learned in the various social spaces seems to be one of the main ways of confronting this scenario, and will require multiple experiences and strategies that contemplate comprehensive care with a view to mitigate the multiple sufferings investigated here. Thus, in addition to the care provided within institutional spaces, the articulation of other sectors of society - such as education, health care and the justice system - also seems essential. In this sense, the overcoming of purely punitive measures, with the production of authentically inclusive environments, may be an interesting strategy. 


\section{Study limitations}

It is important for the data produced in this study to be interpreted in light of its limitations. The first is inherent to the study design itself, in which outcome and exposure were measured simultaneously. This makes it impossible for the results to be used for establishing causal relationships. The second limitation is related to the possible presence of memory bias, especially in the attempt to gather information on events that preceded adolescents' admittance to institutional shelters. Moreover, data on distressful experiences considered less serious may be underreported and should be interpreted with caution. Finally, although the sampling strategy and the effort to cover all public units led to the recruitment of most of the adolescents, the final sample size meant that the confidence intervals had to be extended.

\section{Contributions to public policies}

These limits notwithstanding, the study was able to produce a picture of the distressful experiences lived by this group of adolescents, which is sometimes neglected in the construction of public policies and research agendas. Knowledge on their profiles will certainly enable the (re)construction of strategies able to broaden the view on this topic, analyzing these adolescents' life trajectories and unique experiences, providing care in which the particularity of each subject is centrally positioned in the debate. Thus, we believe that these data can subsidize the production of emancipatory care as well as the building of intersections between social assistance, the justice system and health care, aiming at the denaturalization of violence and the promotion of comprehensive care.

\section{CONCLUSIONS}

This study revealed the multiplicity of distressful experiences lived by adolescents in institutional shelters, previous to their admittance. In the affective-family context, high magnitudes of intimate violence among parents and guardians were identified (again, in moments prior to admittance). These occurred especially in the form of physical violence and grave physical violence. In addition, the use of drugs was also present in research participants' narratives. Peer relationships and individual experiences were shown to be closely related, and violent practices were shown to be persistent in these adolescents' lives. Of particular note are social exclusion, moral harassment at school and in social media, as well as sexual harassment and sexual assault. The data produced here may subsidize new research and qualified interventions in public policies aimed at advancing the rights of these social actors and accomplishing the state's duty to ensure genuine social inclusion for all adolescents.

\section{REFERENCES}

1. Vieira RP, Gomes SHP, Machado MFAS, Bezerra IMP, Machado CA. Participation of adolescents in the Family Health Strategy from the theoretical-methodological structure of an enabler to participation. Rev Latino-Am Enfermagem. 2014;22(2):309-16. doi: 10.1590/0104-1169.3182.2417

2. Fontenele LQ, Miranda LL. Adolescência(s): produções e atravessamentos discursivos em análise. Trends Psychol. 2017;25(3):969-82. doi: 10.9788/tp2017.3-04

3. Correia J, Santos AJ, Freitas M, Ribeiro O, Rubin K. As relações entre pares de adolescentes socialmente retraídos. Aná Psicológica. 2014;32(4):467-79. doi: 10.14417/ap.870

4. Glick GC, Rose AJ. Prospective associations between friendship adjustment and social strategies: friendship as a context for building social skills. Dev Psychol. 2011;47(4):1117-32. doi: 10.1037/a0023277

5. Purves RI, Stead M, Eadie D. "I wouldn't be friends with someone if they were liking too much rubbish": a qualitative study of alcohol brands, youth identity and social media. Int J Environ Res Public Health. 2018;15(2):E349. doi: 10.3390/ijerph15020349

6. Figueiredo VC, Szklo AS, Costa LC, Kuschnir MCC, Silva TLN, Bloch KV, et al. ERICA: smoking prevalence in Brazilian adolescents. Rev Saúde Pública. 2016;50(Suppl 1):12s. doi: 10.1590/S01518-8787.2016050006741

7. Silins E, Horwood L, Naiman JM, Patton GC, Toumbourou JW, Olsson CA, et al. Adverse adult consequences of different alcohol use patterns in adolescence: an integrative analysis of data to age 30 years from four Australasian cohorts. Addiction. 2018;113(10):1811-25. doi: 10.1111/add.14263

8. Kaufman-Parks AM, DeMaris A, Giordano PC, Manning WD, Longmore MA. Parents and partners: Moderating and mediating influences on intimate partner violence across adolescence and young adulthood. J Soc Pers Relat. 2017;34(8):1295-323. doi: 10.1177/0265407516676639

9. Jaffee SR, Ambler A, Merrick M, Goldman-Mellor S, Odgers CL, Fisher HL, et al. Childhood maltreatment predicts poor economic and educational outcomes in the transition to adulthood. Am J Public Health. 2018;108(9):1142-7. doi: 10.2105/AJPH.2018.304587

10. Sharma B, Nam EW, Kim HY, Kim JK. Factors associated with suicidal ideation and suicide attempt among school-going urban adolescents in Peru. Int J Environ Res Public Health. 2015;12(11):14842-56. doi: 10.3390/ijerph121114842

11. Schaefer JD, Moffitt TE, Arseneault L, Danese A, Fisher HL, Houts R, et al. Adolescent victimization and early-adult psychopathology: approaching causal inference using a longitudinal twin study to rule out noncausal explanations. Clin Psychol Sci. 2018;6(3):352-71. doi: $10.1177 / 2167702617741381$

12. Casa Civil (BR). Subchefia para assuntos jurídicos. Lei no 8.069, de 13 de julho de 1990. Dispõe sobre o Estatuto da Criança e do Adolescente e dá outras providências [Internet]. Brasília: Casa Civil; 1990 [cited 2018 Apr 08]. Available from: http://www.planalto.gov.br/ccivil_03/LEIS/ L8069.htm 
13. Rafael RMR, Moura ATMS. Considerações éticas sobre pesquisas com mulheres em situações de violência. Rev Bras Enferm. 2013;66(2):28790. doi: 10.1590/S0034-71672013000200021

14. Ministério Público do Estado do Rio de Janeiro (MPRJ). Censo da população infanto-juvenil acolhida no Estado do Rio de Janeiro [Internet]. Rio de Janeiro: MPRJ; 2015 [cited 2018 Apr 08]. Available from: http://mca.mp.rj.gov.br/wp-content/uploads/2015/11/Apresentacao.pdf

15. Nascimento OC, Costa MCO, Freitas KS, Hebert M, Moreau C. Adaptação transcultural do inventário Parcours Amoureux des Jeunes - PAJ de origem canadense para o contexto brasileiro. Ciênc Saúde Colet. 2015;20(11)3417-26. doi: 10.1590/1413-812320152011.02912015

16. WHO ASSIST Working Group. The Alcohol, Smoking and Substance Involvement Screening Test (ASSIST): development, reliability and feasibility. Addiction. 2002;97(9):1183-94. doi: 10.1046/j.1360-0443.2002.00185.x

17. Henrique IFS, De Micheli D, Lacerda RB, Lacerda LA, Formigoni MLOS. Validação da versão brasileira do teste de triagem do envolvimento com álcool, cigarro e outras substâncias (ASSIST) 2.0. Rev Assoc Med Bras. 2004;50(2):199-206. doi: 10.1590/S0104-42302004000200039

18. Wolfe DA, Scott K, Reitzel-Jaffe D, Wekerle C, Grasley C, Straatman AL. Development and validation of the conflict in adolescent dating relationships inventory. Pscychol Assess. 2001;13(2):277-93. doi: 10.1037/1040-3590.13.2.277

19. Oliveira QBM, Assis SG, Njaine K, Oliveira RVC. Violência nas relações afetivo-sexuais. In: Minayo S, Assis S, Njaine K, organizadoras. Amor e violência: um paradoxo das relações de namoro e do 'ficar' entre jovens brasileiros. Rio de Janeiro: Fiocruz; 2011. p. 87-151. doi: $10.7476 / 9788575413852$

20. Domenach JM. La violencia [Internet]. In: Domenach JM, Laboriti H, Joxe A, Galtung J, Senghaas D, Klineberg O, et al., editors. La violencia y sus causas. Paris: Organización de las Naciones Unidas para la Educación, la Ciencia y la Cultura (Unesco); 1981 [cited 2018 Apr 08]. p. $33-46$. Available from: https://unesdoc.unesco.org/ark:/48223/pf0000043086_spa

21. Krug EG, Dahlberg LL, Mercy JA, Zwi A, Lozano R, editores. Relatório mundial sobre violência e saúde [Internet]. Genebra: Organização Mundial da Saúde; 2002 [cited 2015 Sep 17]. Available from: http://www.opas.org.br/wp-content/uploads/2015/09/relatorio-mundialviolencia-saude.pdf

22. Rafael RMR, Moura ATMS, Tavares JMC, Ferreira REM, Camilo GGS, Neto M. Profile of intimate partner violence in Family Health Units. Rev Bras Enferm [Internet]. 2017;70(6):1259-67. doi: 10.1590/0034-7167-2016-0007

23. Rafael RMR, Moura ATMS. Violência contra a mulher ou mulheres em situação de violência? Uma análise sobre a prevalência do fenômeno. J Bras Psiquiatr. 2014;63(2):149-53. doi: 10.1590/0047-2085000000019

24. Moraes CL, Oliveira AGS, Reichenheim ME, Gama SGN, Leal MC. Prevalência de violência física entre parceiros íntimos nos primeiros seis meses após o parto no município do Rio de Janeiro, Brasil. Cad Saúde Pública. 2017;33(8):e00141116. doi: 10.1590/0102-311x00141116

25. Waiselfisz JJ. Mapa da violência 2014:os jovens do Brasil [Internet]. Rio de Janeiro: Flacso; 2014 [cited 2019 May 17]. Available from: https:// www.mapadaviolencia.org.br/pdf2014/Mapa2014_JovensBrasil_Preliminar.pdf

26. Barbosa PV, Wagner A. A autonomia na adolescência: revisando conceitos, modelos e variáveis. Estud Psicol. 2013;18(4);639-48. doi: $10.1590 /$ S1413-294X2013000400013

27. Silva CJP, Ferreira EF, Paula LPP, Naves MD, Vargas AMD, Zarzar PMPA. A violência urbana contra crianças e adolescentes em Belo Horizonte: uma história contada através dos traumas maxilofaciais. Physis. 2011;21(3):1103-20. doi: 10.1590/\$0103-73312011000300018

28. Ribeiro IMP, Ribeiro AST, Pratesi, R, Gandolfi L. Prevalência das várias formas de violência entre escolares. Acta Paul Enferm. 2015;28(1):54-9. doi: 10.1590/1982-0194201500010

29. Patterson G, Reid J, Dishion, T. Antisocial boys. Eugene: Castalia Publish Company; 1992.

30. Instituto de Pesquisa Econômica Aplicada (Ipea), Fórum Brasileiro de Segurança Pública (FBSP). Atlas da Violência 2018 [Internet]. Brasília: Ipea, FBSP; 2018. [cited 2018 Aug 15]. Available from: http://www.forumseguranca.org.br/wp-content/uploads/2018/06/FBSP_Atlas_da_ Violencia_2018_Relatorio.pdf

31. Macedo, E. Violência entre parceiros íntimos (VPI): problema e sintoma no panorama das violências sobre as mulheres. Ex Aequo [Internet]. 2015 [cited 2018 Aug 15];31:29-44. Available from: http://www.scielo.mec.pt/pdf/aeq/n31/n31a04.pdf

32. Cariranha Jl, Penna LHG. Violência vivenciada pelas adolescentes acolhidas em instituição de abrigamento. Texto Contexto Enferm. 2012;21(1):68-76. doi: 10.1590/S0104-07072012000100008

33. Milgram S. Behavioral study of obedience. J Abnorm Soc Psychol. 1963;67(4):371-8. 